\title{
Unintended but not unanticipated consequences
}

\author{
Frank de Zwart ${ }^{1}$
}

Published online: 12 April 2015

(C) The Author(s) 2015. This article is published with open access at Springerlink.com

\begin{abstract}
The concept "unanticipated consequences," coined by Robert K. Merton (1936), has largely been replaced in current social science by its putative synonym, "unintended consequences." This conflation suggests that "unintended" consequences are also "unanticipated," effectively obscuring an interesting and real category of phenomena-consequences that are both unintended and anticipated-that warrant separate attention. The first part of this article traces the conflation of "unintended" and "unanticipated," and explains why it occurred. The second part argues the need for a clear distinction between what is unintended and what is unanticipated, and it illustrates the failure of the present concept of "unintended consequences" to do so and the consequences that has for social and political analysis.
\end{abstract}

Keywords RobertK. Merton - Unanticipated consequences · Unintended consequences · Public policy · Multiculturalism · Quagmire

"Unintended consequences" remain a preoccupation in the social sciences, with its annals containing an ever-expanding collection of examples on the unwelcome sideeffects of policy. ${ }^{1}$ This article does not add to this collection but seeks to narrow it by questioning the pervasive conflation of "unintended" and "unanticipated" consequences, a habit that stems from mixing up two theoretical traditions: that of

\footnotetext{
${ }^{1}$ Alejandro Portes in his 1999 presidential address to the American Sociological Association described sociology as the "analysis of the unexpected" and paid homage to Merton for pioneering research on the theme: "Written more than 60 years ago, Merton's (1936) article, "The Unanticipated Consequences of Purposive Social Action," continues to be as relevant today as when it was first published" (Portes 2000, p. 7).
}

Frank de Zwart

zwart@fsw.leidenuniv.nl

1 Department of Political Science, Leiden University, Wassenaarseweg 52, PO Box 9555, 2300

RB Leiden, The Netherlands 
"unintended consequences" from the spontaneous order literature and that of "unanticipated consequences" following Merton (1936). These traditions, while closely related, are not the same. Conflating their main ideas, I argue, subverts precision and hinders our understanding of consequences that while unintended are not unanticipated.

The idea that individual self-interested acts can produce benign aggregate outcomes that were neither intended nor foreseen is central to the spontaneous order tradition. ${ }^{3}$ Carl Menger, its main nineteenth-century representative, observed:

Institutions which serve the common welfare and are extremely significant for its development . . . come about as the unintended result of individual human efforts (pursuing individual interests) without a common will directed toward their establishment. (1985 [1883], pp. 146, 133)

Merton's 1936 article "Unanticipated Consequences of Purposive Social Action" builds on this tradition, but with an important difference. Merton was interested in the consequences of "formally organized" action, not the unorganized actions of "individuals considered distributively" (1936, p. 896). "Unanticipated consequences," Merton writes,

may, of course, follow both [unorganized and organized] action, though the second type would seem to afford a better opportunity for sociological analysis since the very process of formal organization ordinarily involves an explicit statement of purpose and procedure. (Merton 1936, p. 896)

The literature on unintended consequences following Merton (1936) agrees, with most authors focusing on the unintended consequences of organized action, meaning the unwelcome outcomes of formal policy.

The distinction is important because the failure to anticipate outcomes is far from self-evident in organized action, whereas in a spontaneous order - the aggregate outcome of numerous unorganized individual actions - lack of anticipation is a given. ${ }^{4}$ Anticipating the outcomes of purposive action is the core business of policy makers. They frequently fail, of course, and Merton aims to explain why. Still, I argue, policy makers foresee more than we give them credit for. ${ }^{5}$ Merton's choice of terms

\footnotetext{
$\overline{2}$ The term "spontaneous order" was coined by Polanyi (1951) and later adopted by Hayek (1982). It refers to the classic problem of social phenomena that are "the result of human action, but not the execution of any human design," in Adam Ferguson's seminal phrase (1995 [1767], p. 205). Spontaneous order was a central concern of the eighteenth-century Scottish Enlightenment and the nineteenth-century Austrian School of Economics. See Barry (1982) for an instructive account.

${ }^{3}$ As Adam Smith famously phrased it: "The rich, . . . in spite of their natural selfishness and rapacity, though they mean only their own conveniency, though the sole end which they propose from the labours of all the thousands whom they employ, be the gratification of their own vain and insatiable desires, . . are led by an invisible hand to, ... . without intending it, without knowing it, advance the interest of the society, and afford means to the multiplication of the species" (1982 [1759], pp. 184-185).

4 "Every step and every movement of the multitude . . . are made with equal blindness to the future" (Ferguson 1995 [1767], p. 119). See also Hayek (1982, pp. 35-52).

${ }^{5} \mathrm{Cf}$. Hirschman: "I intend to raise some doubts about [perverse effects] occurring with the frequency that is claimed. . . . Policy making is a repetitive, incremental activity . . . so that tendencies toward perversity stand a good chance of being detected and corrected" (1991, pp. 38, 42). This article adds another option: perverse effects also stand a good chance of being detected, even anticipated, without being corrected.
} 
("unanticipated" rather than "unintended") was by no means arbitrary; it clearly distinguishes unanticipated consequences from, say, those that are unintended but anticipated. Unfortunately this clarity was obscured by the later conflation of "unintended" and "unanticipated"-a development to which Merton himself contributed.

\section{Disappearance of the unanticipated}

While Merton's 1936 article only referred to "unanticipated consequences," Social Theory and Social Structure (1968) used "unintended consequences" and "unanticipated consequences" as synonyms. While both were common terms in social science publications in the $1950 \mathrm{~s}$, references to "unintended consequences" began to outnumber "unanticipated consequences" in the early 1960s. As the Ngram ${ }^{6}$ below shows, "unintended consequences" is today the standard term while "unanticipated consequences" has all but fallen out of use.

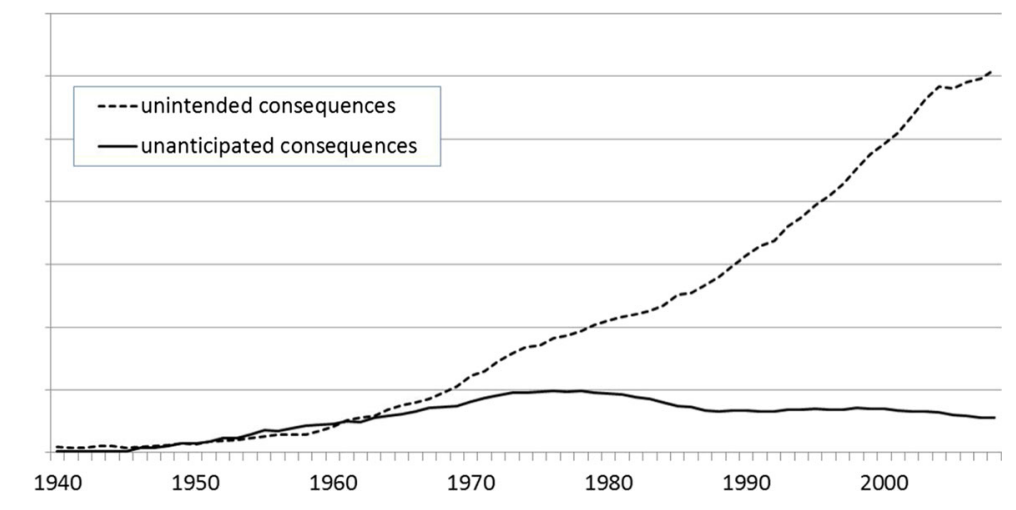

Source: based on data from Google Ngram

Fig. 1 Unintended consequences and unanticipated consequences 1940-2008. Source: based on data from Google Ngram

Google Scholar confirms the picture, generating 110,000 hits for "unintended consequences" and 15,100 for "unanticipated consequences." Google Web likewise yields 5,880,000 hits for "unintended consequences" and 147,000 for "unanticipated consequences."

Does the declining use of "unanticipated consequences" reflect a change in the real world? Or has it simply been replaced by "unintended consequences" as a synonym? A change in the real world would imply that our ability to anticipate the effects of purposive social action has improved over time. To some extent this is true. Policy makers now have more facts and theories at their disposal while the unintended consequences of policy are a widely recognized problem. Strategies

\footnotetext{
${ }^{6}$ An Ngram pictures the frequency, over time, with which terms appear in Google books, a database including 5.2 million books.
} 
for avoiding unintended consequences are standard fare in management handbooks and manuals while public administration schools teach the "science of muddling through" (Lindblom 1959). While Merton's pioneering work on unanticipated consequences (1936) placed the issue on the agenda, it became a selfdefeating prophecy.

If greater awareness among policy makers explains the decline in references to unanticipated consequences, how should we understand the simultaneous increase in references to unintended consequences? If unintended effects are anticipated, they are a different phenomenon as they follow from purposive choice and not, like unanticipated effects, from ignorance, error, or ideological blindness (Merton 1936). Which of these do we mean when we call something an unintended consequence?

The literature is far from clear on this point, with some authors stressing the difference between unintended and unanticipated effects. Whereas Giddens's definition of unintended consequences as "consequences which result from behavior initiated for other purposes" (1993, p. 765) clearly distinguishes between the two, ${ }^{7}$ most authors gloss over the issue and use "unintended" as a synonym for "unanticipated." The Blackwell Dictionary of Sociology, for instance, notes that "[f] unctionalists distinguish between "manifest consequences that are anticipated and latent consequences (or unintended consequences) that are not" (Johnson 1995, p. 117). The Oxford Dictionary of Sociology, under the section-heading "unintended or unanticipated consequences," says: "the theme of the unintended consequences of action ... has [a] large pedigree in the social sciences [because] things do not always turn out as we expect" (Scott and Marshall 1998, p. 680; cf. Marshall 1998). In Wikipedia we read that in the social sciences, "unintended consequences (sometimes unanticipated consequences or unforeseen consequences) are outcomes that are not the outcomes intended by a purposeful action [sic]." The Concise Encyclopedia of Economics tells us that "the law of unintended consequences, often cited but rarely defined, is that actions of people - and especially of government-always have effects that are unanticipated or unintended" (Norton 2008).

Unanticipated consequences, so it seems, are disappearing from the literature because they are being called by another name: "unintended consequences." The two have been mistakenly conflated. True, unanticipated consequences can only be unintended, but unintended consequences can be either anticipated or unanticipated, a distinction lost in the single opposition of "intended" versus "unintended." 8 Table 1 illustrates:

The left bottom cell is empty because what is intended cannot be unanticipated, and vice versa. Intended consequences can only be anticipated (A). But unintended consequences can be either anticipated or unanticipated (B or D).

The focus when theorizing unintended consequences has been on $\mathrm{A}$ and $\mathrm{D}$. A represents the rational ideal-purposive action realizes intentions; $\mathrm{D}$ is the realm of

\footnotetext{
${ }^{7}$ See also Boudon (1982, p. 8); Giddens (1977, pp. 107-108); Perri 6 (2010); Sen (1999, p. 257).

${ }^{8}$ Huntington notes a similar problem with the modern-traditional dichotomy. He cautions that oppositions between positive concepts ("modern") and residual ones ("traditional") are "dangerous analytically [because] they obfuscate the diversity which may exist in the residual phenomenon" (1971, p. 294). "Unintended consequences" is one such residual concept.
} 
Table 1 Consequences of purposive action

unexpected outcomes, the core subject of the social sciences according to many. ${ }^{9}$ Our concern here is B, unintended but anticipated outcomes. Like D (unintended and unanticipated), B consists of "things nobody wants," ${ }^{10}$ but unlike D, things under B are foreseen. Category B effects are real and common, and, as noted, in need of separate attention. An obvious example is the unwelcome side effects of medicine. Doctors who prescribe a drug do not intend to produce side effects - they intend to cure a disease or relieve pain - but anticipate them and weigh their harm against intended benefits. Weighing intended and unintended effects may be a matter of routine, as when prescribing medicines, but may also entail a choice with political or moral significance as in certain policy decisions. The point is that conflating unintended and unanticipated consequences obscures category B and with it the choices that were made.

Consider the following contribution to the International Encyclopedia of Political Science (2011) on "performance management":

In the performance management debate, warnings are given about the dysfunctions and unintended consequences of performance management practices that may result in a decline rather than an improvement in the performance of organizations. . . . Such effects may include ... growth of internal bureaucracy .. . lack of innovation, . . . tunnel vision, [and] measure fixation (Salminen 2011, p. 1855).

Conventional usage suggests that "unintended consequences" are unanticipated. But the unwelcome effects listed above are hardly surprising, with ample documentation of bureaucratization, tunnel vision, and measure fixation in the handbooks and academic literature on performance management. ${ }^{11}$ Anticipating these unintended consequences is not beyond the ability of an educated performance manager; to assume that they are unforeseen indeed seems naive. They are more likely unintended but anticipated consequences, unwelcome side effects that were foreseen but traded-off against intended consequences-efficiency gains - and thus accepted.

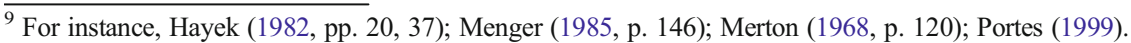

${ }^{10}$ Karl Popper wrote in 1963: "People who approach the social sciences with a ready-made conspiracy theory thereby deny themselves the possibility of ever understanding what the task of the social sciences is, for they assume that we can explain practically everything in society by asking who wanted it, whereas the real task of the social sciences is to explain those things which nobody wants" (1963, pp. 124-125).

${ }^{11}$ Merton's theory of "goal displacement" (1940) mentions them all. See also Gouldner (1954) and numerous critiques of "new public management," e.g., Bouckaert and Balk (1991); Van Thiel and Leeuw (2002).
} 
While this hypothesis would require testing case by case, the basic point remains: the current standard usage of "unintended consequences" with its suggestion of "unanticipated" encourages us to overlook the issue. Before pursuing this point, we first examine how and why the two concepts were conflated.

\section{Survival of the unintended}

While Merton's seminal article "Unanticipated Consequences of Purposive Social Action" (1936) strictly focused on "unforeseen" effects (1936, p. 895), ${ }^{12}$ Merton in Social Theory and Social Structure (1968) uses "unintended consequences" and "unanticipated consequences" as synonyms. ${ }^{13}$ Here is a familiar example:

The distinctive contributions of the sociologist are found primarily in the study of unintended consequences (among which are latent functions) of social practices, as well as in the study of anticipated consequences (among which are manifest functions). (1968, p. 120)

The above passage and those cited below have contributed much to establishing the use of "unintended" and "unanticipated" as synonyms. Social Theory and Social Structure is one of the most cited studies in social science (and these are some of its most cited passages), while the vast literature ensuing from this study has reproduced the habit. ${ }^{14}$ It is no coincidence that the rise in references to "unintended consequences" shown in Fig. 1 began shortly after 1957 when the revised (and most quoted) edition of Social Theory and Social Structure was published.

Why did Merton not stick to "unanticipated" consequences as he did in $1936 ?$ Why muddy the issue by referring to "unintended" consequences, which are not the same thing? The reason is that Merton in Social Theory and Social Structure (1968) uses his ideas about "unanticipated consequences" to foster functionalist explanation, and in doing so takes a radical step away from the 1936 article. ${ }^{15}$ In 1936 Merton explained unanticipated consequences of purposive behavior; in 1968 he switches explanans and explanandum and explains behavior by its consequences (cf. Elster 1990, pp. 131-132). Intended consequences become "manifest functions" and unintended consequences become "latent functions" (1968, pp. 114-118):

\footnotetext{
12 The term "unintended consequences" appears once in this article, casually, when Merton notes the difficulty "of discriminating between rationalization and truth in those cases where apparently unintended consequences are post facto declared to have been intended" (Merton 1936, p. 897).

13 "Unintended consequences" does not appear in the index of Social Theory and Social Structure, though in the text it is used as a synonym for "unanticipated consequences."

${ }^{14}$ A telling example is Tilly and Goodin (2006) who refer to Merton's 1936 article as "The Unintended [sic] Consequences of Purposive Social Action" (2006, pp. 22, 30). Commenting on this mistake, Marcel van der Linden (2010, p. $282 \mathrm{fn}$.) notes that "[e]ven the best of us sometimes lose sight of the difference [between unintended and unanticipated consequences]." Although he is obviously right, it should be noted that the source of this conflation is Merton himself.

${ }^{15}$ According to Arnold Zingerle, Merton's argument of 1936 has all the traits of a "prefunctionalist actiontheory design," which is why in the decades after mainstream social science with its "collectivist orientation in theory" lost sight of it (1998, p. 178, see also note 19 below).
} 
This is the rationale for the distinction between manifest functions and latent functions; the first referring to those objective consequences for a specified unit. . . which contribute to its adjustment and adaptation and were so intended; the second referring to unintended and unrecognized consequences of the same order. (1968, p. 117)

Both types of functions can explain behavior, but latent functions explain behavior irrespective of the intentions of the actor. ${ }^{16}$ In other words, whether or not they intend it, people act in certain ways because those acts contribute to the persistence of a larger structure. ${ }^{17}$ The distinction between manifest and latent functions rests on the presence or absence of actors' intentions. This is why Merton used "unintended" instead of "unanticipated consequences" - to accentuate the crux of latent function explanation. Merton's use of the two concepts as synonyms then became standard usage, living on long after functionalism's fall into obsolescence. Numerous critiques have pointed out that latent function explanations are teleological as they fail to provide mechanisms of selection or reinforcement (Elster 1989, pp. 98-100). But this critique applies unevenly to Merton's main examples. His latent function explanation of the Hopi rain dance is teleological; his explanation of political machines is not.

The Hopi rain dance, Merton assumes, does not fulfill its manifest function of causing rain. Thus the question is why it occurs at all. "It may be found," he suggests, "that the ceremonial does indeed have functions-but functions which are non-purposed or latent. Ceremonials may fulfill the latent function of reinforcing the group identity" (1968, pp. 118-119). But this does not suffice to explain the occurrence of the rain dance. The dance might produce social cohesion and indeed probably does. But if the Hopi do not intend or recognize this function, it cannot explain their participation unless we provide a mechanism of selection or reinforcement, which Merton does not. No Hopi informant who reports joining the rain dance to reinforce group identity is ever mentioned. And if he were, the function would cease to be latent as the behavior to be explained would no longer be "non-purposed."

Merton's explanation of political machines, however, does provide a "mechanism of reinforcement." For Jon Elster, Merton is an exponent of the Main Functionalist Paradigm, which yields teleological explanations because "it postulates a purpose without a purposive actor" (1982, p. 454). Although Elster assumes that explanation by function and explanation by purpose are mutually exclusive, Merton shows that this is not the case. Merton explains political machines by the functions they fulfill for individuals:

For . . . big business . . the political boss serves the function of providing those political privileges which entail immediate economic gains .... To those in need . . . the machine . . . fulfills the important social function of humanizing and

\footnotetext{
${ }^{16}$ Merton distinguishes latent functions to stress that motives and functions vary independently, and to "preclude the inadvertent confusion often found in sociological literature between conscious motivations for social behavior and its objective consequences" (1968, p. 114).

17 A "given system" or "specified unit," as in Merton (1968, p. 117), or a "social whole" in the structuralfunctionalism of Parsons (1951) and Radcliffe-Brown (1952).
} 


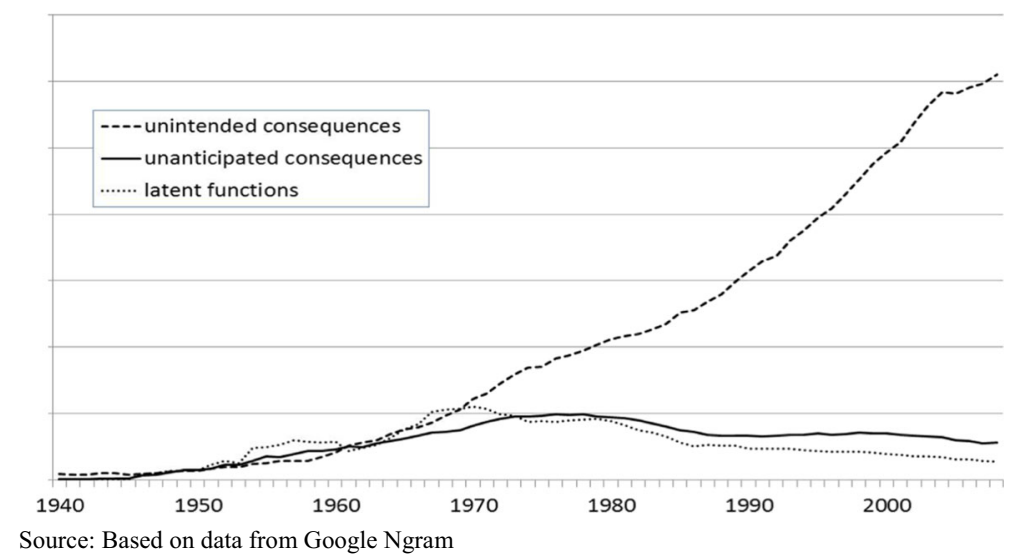

Fig. 2 Unintended consequences, unanticipated consequences, and latent functions 1940-2008. Source: Based on data from Google Ngram

personalizing all manner of assistance. ... The distinctive function of the political machine for their criminal, vice, and racket clientele is to enable them to operate . . . without due interference from the government. (Merton 1968, pp. 129, 128, 134)

The mechanisms are clear: the political boss helps those who repay him with their support; people support a boss who has something to offer. Both parties expect to gain from the relationship, and as long as they do the machine persists. But explanation by these functions for individuals would make no sense without purposive actors. After all, the machine can be functional only for people who pursue some goal-such as obtaining aid or protection. Merton's explanation of political machines therefore violates his own definition of latent functions as unintended and unrecognized; he instead views latent functions as covert or tacit (not as unintended or unrecognized) purposes. $^{18}$

The specifics of this functionalist explanation of political machines were never widely recognized (De Zwart 1994). ${ }^{19}$ When functionalism lost its appeal in the late 1970 s, so did latent function explanation, now associated with the teleology of the rain dance example. But the concept of "unintended consequences" did not disappear with it. We should have either retired it as a functionalist holdover of the rain dance kind and returned to the clearer concept of "unanticipated consequences" (which are "unintended" by definition) or used it consistently with the qualification "anticipated" (or not).

\footnotetext{
${ }^{18}$ I elaborate on this in De Zwart (1994, pp. 182-185).

${ }^{19}$ Campbell (1982) is an exception: He blames Merton's functionalism not for its neglect of purposive actors, but for its focus on that. Merton remains within the "limited sphere of rational purposive action," he argues, to the neglect of "subconscious intention," "non-rational action," and "nonintentional subjective dispositions" (1982, pp. 37, 35). To illustrate this point Campbell uses a cross-classification of "intention" and "recognition," somewhat alike to what we did above for "unintended" and "unanticipated" (ibid., pp.3435). Although I disagree with Campbell's conclusion, I think he is right that Merton, in line with contemporary action theory, equated action with purposive action. This may also explain why Merton removed "purposive" from the title in a reprint (1976) of his 1936 article; "purposive action" is a pleonasm.
} 
Merton himself did the latter. In an [relatively recent] autobiographical account of his oeuvre (1998), he builds on his pre-functionalist (1936) argument, stressing the unforeseen effects of purposive action. The article is brief on manifest and latent functions, and refers to "unintended consequences" only as "unintended and unanticipated consequences" (ibid., pp. 295, 296, 298). Moreover, Merton notes that most of his work is "linked with the core idea of unanticipated consequences, later differentiated into unanticipated, unintended, and unrecognized consequences" (ibid., p. 315). ${ }^{20}$ I doubt that "differentiation" is the right term here since the fate of these concepts was conflation, not differentiation. Moreover, Fig. 2 shows that "unintended consequences" did not go the way of structural functionalism; rather, it was "unanticipated consequences" that disappeared from the literature along with "latent functions," while the unqualified use of "unintended consequences" thrives.

Why was the clearest of these putative synonyms abandoned? One important reason, it seems, is linguistic convenience. "Unintended" has a rhetorical advantage over "unanticipated" because it is semantically closer to "unwanted" and almost all studies about "unintended consequences" today are about the unwanted side-effects of policy. ${ }^{21}$

\section{Presumed ignorance}

The standard meaning of "unintended consequences" today is unwelcome and unanticipated policy outcomes. As such, it fits well within organization theory, which tends to focus on organizational shortcomings rather than accomplishments (Stinchcombe 2001, pp. 1-17). In light of well-established theories such as "goal displacement," "garbagecan" decision making, "institutionalization," "isomorphism," "bounded rationality," and "muddling through," it is hardly surprising that failure to anticipate unwelcome consequences is the rule rather than the exception in policy making. Students of bureaucracy theory are well prepared to accept this. But what about unintended yet anticipated effects?

Consider this example: official statistics show that China's overall sex ratio at birth was 118 boys for 100 girls in 2010. "If the trend continues," the director of National Population and Family Planning Commission stated at a press conference, ${ }^{22}$ "it will jeopardize gender equality, development of girls, lawful interests and rights of women, and the nation's long-term development." The female population deficit is often explained as an unintended consequence of China's one-child policy (e.g., Shalev 2001; Ebenstein 2010; Legge and Zhao 2004). To assure male offspring under the constraint of the one-child policy, households practice "sex selection" (Ebenstein 2010, p. 5), which results in a national female population deficit. Sex selection is a household

\footnotetext{
${ }^{20}$ Merton is unclear about the sequence of intellectual events. A few pages earlier he also remarks on "later differentiation," though the sequence is reversed: "For the theme of unintended consequences - only later differentiated from unanticipated and unrecognized consequences - had pervaded my doctoral dissertation" (1998, p. 302).

${ }^{21}$ Hirschman, who also identifies unintended with unanticipated consequences, says that once Adam Smith's concept of the "Invisible Hand . . became famous and evolved into "unanticipated" or "unintended" consequences, it soon acquired negative connotation, as "unintended easily slides over to undesired" (Hirschman 1991, p. 38) In a footnote on the same page Hirschman adds that "This shift of meaning took place in spite of Robert Merton's warning that 'unforeseen consequences should not be identified with consequences which are necessarily undesirable."

${ }^{22}$ http://news.xinhuanet.com/english2010/china/2011-08/16/c_131052436.htm (accessed August 23, 2013).
} 
choice for the lesser of two evils that produces unintended outcomes (cf. Aya 2006, p. 118). But what about anticipation? If we think of the deficit as resulting from a multitude of household decisions, it is an "effect of aggregation" (Boudon 1982, pp. 139-140). ${ }^{23}$ There is no organization or design, only numerous separate households who prefer sons over daughters and act accordingly. In this situation, lack of anticipation is more or less a given, as in the afore-mentioned spontaneous order tradition.

But if the female deficit is an unintended consequence of the one-child policy, we invoke organized action and that changes the situational logic. The Chinese government introduced the one-child policy to curb population growth; the female population deficit is its unintended consequence. But lack of anticipation is hardly a given here. Ebenstein concludes that "encouraging or forcing people to change their fertility behavior without addressing their fundamental preferences may have unanticipated consequences" (2010, p. 31). ${ }^{24}$ But why presume ignorance here? Governments specialize in anticipation; is it really likely that the Chinese government was unaware of the mechanism described above and did not foresee its consequences?

According to Greenhalgh (2008, pp. 267-268), makers of the one-child policy and other government officials anticipated the female population deficit. But it did not keep them from pursuing the policy. Instead they banned the issue of sex ratio imbalance from public debate and stifled research on it. "[S]cholars were forbidden to address the question of female infanticide or even the SRB [sex ratio at birth]" (ibid., p. 267). But "party propagandists were well aware of the possibility that . . rural couples might abandon or even kill their infant daughters" (ibid., p. 356 fn.). Indeed cadres in rural areas were instructed to teach gender equality and to urge the population to overcome old ideas about the superiority of sons. China's female population deficit, then, is better characterized as an unintended but anticipated consequence.

Consider another example. Asari et al. (2008) write about what they see as one of the major problems facing contemporary British society: "the failure to produce a discourse that integrates various ethnic groups under the umbrella of a common British identity" (2008, p. 1). The pursuit of multiculturalism, they write, "reinforces ethno-cultural elements of identity. Indeed, the way multiculturalism has been implemented in Britain has proven problematic, with the unintended consequence of causing segregation and disunity" (ibid., p. 13). Left unqualified, "unintended" in conventional usage suggests lack of anticipation. But the risk of segregation has been a standard critique of multiculturalism since its inception, a risk policy makers around the world are keenly aware of (De Zwart 2000, 2005; Schraml 2011). ${ }^{25}$ Segregation is an unwelcome but anticipated side effect: it is permitted because it is traded off against intended effects such as managing immediate crises and promoting equal cultural recognition. ${ }^{26}$

\footnotetext{
${ }^{23}$ Jon Elster's account of flourishing banditry in traditional China is an example. Many poor families in traditional China practiced female infanticide. The result was a surplus of boys and unmarried men who "were excellent material for recruitment by bandits" (1989, p. 97). Banditry prospered as an unintended consequence.

${ }^{24}$ Ebenstein consistently uses "unintended" throughout the article but here, in the conclusion, shifts to "unanticipated" as a synonym.

${ }^{25}$ Policy makers here face "the dilemma of recognition"-wishing to mitigate group inequalities while foreseeing that the policies required to do so will accentuate the very group differences that caused the problem in the first place (De Zwart 2005, p. 137).

${ }^{26}$ Koopmans (2010) rightly argues that cultural recognition - a normative reason for state-sponsored multiculturalism - entails "real trade-offs with the goals of socio-economic participation and equality" (2010, p. 22). But does the government need to be told it makes tradeoffs when it makes them deliberately?
} 
The analysis of unintended consequences in public sector reform, Guy Peters writes, makes "reformers appear terribly naïve so that they would not understand just what they are doing, but generally these reformers [simply have] to make difficult choices in complex situations" (2007, p. 23). What makes reformers appear naïve, I would add, is the habit of using unintended as a synonym for unanticipated, whereas in reality reformers must often make "difficult" choices - difficult precisely because they foresee unwelcome effects. Conflating "unintended" and "unanticipated" obscures this.

Why, then, does this conflation remain so pervasive? One reason is that all parties involved in the analysis of unintended consequences benefit from it. Discovering and exposing the unforeseen lends importance to the work of analysts. ${ }^{27}$ In their account of popular explanations of world inequality, Acemoglu and Robinson (2013) draw attention to "the ignorance hypothesis, which asserts that world inequality exists because we or our rulers do not know how to make poor countries rich" (2013, p. 63). This hypothesis, they argue, "rules supreme among most economists and in Western policy making circles" (ibid.). One of its charms is that it promises a way out: if ignorance is the cause of world inequality, more knowledge and good advice to policy makers can solve the problem (ibid., p. 67). But the ignorance hypothesis is often wrong and highly misleading, as Acemoglu and Robinson convincingly show (ibid., pp. 63-70). "Leaders of African nations," for instance,

that have languished over the last half century under insecure property rights and economic institutions, impoverishing much of their populations, did not allow this to happen because they thought it was good economics [which would make impoverishment an unintended and unanticipated consequence, FdZ]; they did so because they could get away with it and enrich themselves at the expense of the rest, or because they thought it was good politics, a way of keeping themselves in power by buying the support of crucial groups or elites. (ibid., p. 66)

Rulers and policy reformers also benefit from conflating "unintended" and "unanticipated" consequences because it helps them to shed responsibility and avoid discussion about hurtful choices. Daniel Ellsberg's (1972) famous critique of the "quagmire model," a popular explanation for America's disastrous entanglement in the Vietnam War, is a textbook example. The quagmire model, believed by most Americans, holds that a

policy of 'one more step' - each new step always promising the success which the previous last step had also promised but had unaccountably failed to deliver . . . lured the United States deeper into the morass. .. . We have achieved our present entanglement not after due and deliberate consideration, but through a series of small decisions; . . . each step led only to the next, until we find ourselves entrapped in that nightmare of American strategist, a land war in Asia. (Schlessinger [Jr. (1968)] in Ellsberg 1972, pp. 49-50)

\footnotetext{
${ }^{27}$ As Baily Norwood notes: "Economy professors love to make themselves look smart and policy makers look stupid. Hence, we love the Law of Unintended Consequences." http://ageconseeds.blogspot.nl (accessed August 16, 2013).
} 
This theory, Ellsberg notes, seemed plausible to so many because it "accords with the major, widespread presumption that the 'nightmare' outcome must have been unforeseen even as a strong possibility by those who made the decisions leading toward it; or else they would have drawn back, or at least warned the public of the demands ahead" (ibid., p. 50, italics in original). But Ellsberg's research shows that presumption entirely wrong; the quagmire model is a myth, or, in terms of this article, the nightmare outcome may be unintended but it is not unanticipated. The Presidents that made the decisions leading to the "nightmare outcome" did so after having been told, in striking detail, by military and civilian specialists, what this outcome would be. Rather than the US Government lacking foresight and consequently stumbling into quicksand, "one sees, repeatedly, a leader striding with his eyes open into what he sees as quicksand, increasing his efforts and carrying his followers deeper in. Why? Presumably, because he sees no alternative . . . or because the alternatives seem even more threatening, worse in the short run" (ibid., p. 79).

Unintended but anticipated outcomes often concern controversial and politically sensitive issues, and the connotation of "unanticipated" that sticks to "unintended" makes it possible to expose, discuss, or correct such issues without imputing blame or getting into painful discussions about responsibility. "Looking at where their policies and tactics have brought us so far," Ellsberg writes, "it is easy to understand why the past four Presidents would want . . . to conceal and deprecate their own foreknowledge and intentions. ... Presidents and their partisans find comfort and political safety in the quicksand image" (ibid., pp. 127, 131).

The disentangling of unintended and unanticipated consequences foregrounds questions of justification and responsibility, illustrated by a debate among moral philosophers on the "double effect," or the foreseeable causation of harm. At issue is the question of whether a person may "licitly perform an action that he foresees will produce a good effect and a bad effect" (Mangan 1949, p. 43). The principle of double effect - introduced by Thomas Aquinas to justify self-defense ${ }^{28}$-provides a moral justification for such acts if four conditions are met: "1. that the action in itself from its very object be good or at least indifferent; 2. that the good effect and not the evil effect be intended; 3 . that the good effect be not produced by means of the evil effect; 4 . that there be a proportionately grave reason for permitting the evil effect" (ibid.).

The principle of double effect is widely accepted as a moral guideline (Boyle 1980). ${ }^{29}$ A classic illustration condemns the terror bomber but condones the tactical precision bomber, though both anticipate an equal number of civilian casualties. A terror bomber aims at civilians to cause terror; civilian casualties result from his intentions. The tactical bomber intends to take out enemy military targets; civilian casualties are an unintended but anticipated side-effect. The principle of double effect defines terror bombing as morally impermissible but permits tactical bombing. ${ }^{30}$ Some authors, however, are skeptical about the moral significance of the

\footnotetext{
${ }^{28}$ Summa Theologica (II-II, Qu. 64, Art.7). A speech of Osama Bin Laden apologizing to Sunni Muslims in Iraq suggests that the principle's moral appeal is not limited to the Christian world: "The Muslim victims who fall in operations against the infidel Crusaders or their usurper [Iraqi] agents are not the intended targets. . . . We hold ourselves responsible and seek God's forgiveness for that” ([Bin Laden, quoted in Scheuer 2011, p. 5327).

${ }^{29}$ See Krakauer et al. (2000) for examples in medical practice.

${ }^{30}$ McIntyre (2011) discusses a range of other common applications of the principle.
} 
difference between what is intended and what is merely foreseen (McIntyre 2001, 2011); others doubt the extent to which the doctrine of double effect actually codifies moral intuition (Otsuka 2008). As space does not allow more detailed discussion, I mention this here to show that the distinction between intention and anticipation is clearly a question in ethics. But in social science this distinction has been blurred through conceptual conflation.

\section{Conclusion}

I have argued that the concept of "unanticipated consequences" has largely disappeared from the literature because it has been replaced by its putative synonym, "unintended consequences." Merton himself invited this conflation when he incorporated his own earlier thoughts on unanticipated consequences in functionalist explanation. Although he later stressed the need to distinguish these two concepts, he could not undo the lasting influence of his own earlier work: "unintended consequences" has come to mean unforeseen side effects, the study of which is often called the raison d'être of social science. However, this conceptual conflation has rendered invisible another category of outcomes, namely unintended but anticipated consequences. This category does not fit the classic dichotomy between "design" and "spontaneous growth" because unintended but anticipated consequences are neither designed nor generated spontaneously; they are better characterized as "permitted outcomes."

Policy makers in the examples cited above anticipated unwelcome and unintended consequences. That did not, however, keep them from pursuing their plans. We cannot explain these outcomes as arising out of error, ignorance, or blindness as with conventional unintended consequences; the question is not why policy makers failed to anticipate these effects but why, given the foreseen risks, they chose to go ahead anyway. It may be that policy makers are opting for the lesser of two evils, thinking that not acting is worse than permitting the harm they foresee. It may be that they are indifferent to future harm, or simply willing to gamble, hoping things will not turn out too badly. But it may also be that the decisions that produced the unintended harm were carefully weighed on a moral scale as in, for instance, "principle of double effect." The answer depends on the case at hand; the point here is that recognizing unintended but anticipated consequences as a separate category that represents this aspect of social reality can facilitate such research. Social scientists, eager to speak truth to power, should consider the possibility that those in power may know the truth, yet let bad things happen anyway because they fear worse.

Acknowledgments I would like to thank Odile Verhaar, Rod Aya, Rosanne Rutten, Lee Seymour, Paul Nieuwenburg, Francesco Ragazzi, and Michael Meffert for their very useful comments on earlier drafts of this article. Takeo David Hymans provided excellent editorial assistance.

Open Access This article is distributed under the terms of the Creative Commons Attribution License which permits any use, distribution, and reproduction in any medium, provided the original author(s) and the source are credited. 


\section{References}

Acemoglu, D., \& Robinson, J. A. (2013). Why nations fail. The origins of power, prosperity and poverty. London: Profile Books.

Asari, E., Halikiopoulou, D., \& Mock, S. (2008). British national identity and the dilemmas of multiculturalism. Nationalism and Ethnic Politics, 14, 1-28.

Aya, R. (2006). Theory, fact, and logic. In R. Goodin \& C. Tilly (Eds.), The Oxford handbook of contextual political analysis (pp. 114-128). Oxford: Oxford University Press.

Barry, N. (1982). The tradition of spontaneous order: a bibliographical essay. Literature of Liberty: A Review of Contemporary Liberal Thought, 5(2), 1-49.

Bouckaert, G., \& Balk, W. (1991). Public productivity measurement: diseases and cures. Public Productivity \& Management Review, 15(2), 229-235.

Boudon, R. (1982). The unintended consequences of social action. London: Macmillan.

Boyle, J. M. (1980). Toward understanding the principle of double effect. Ethics, 90(4), 527-538.

Campbell, C. (1982). A dubious distinction? An inquiry into the value and use of Merton's concepts of manifest and latent function. American Sociological Review, 47(1), 29-44.

De Zwart, F. (1994). Early transactionalism: Comparing Robert K. Merton and Fredrik Barth on politics. In J. Verrips (Ed.), Transactions: Essays in honor of Jeremy F. Boissevain (pp. 176-187). Amsterdam: Het Spinhuis.

De Zwart, F. (2000). The logic of affirmative action: caste, class and quotas in India. Acta Sociologica, 43(3), 235-251.

De Zwart, F. (2005). The dilemma of recognition: administrative categories and ethnic diversity. Theory and Society, 34(2), 137-169.

Ebenstein, A. (2010). The "missing girls" of China and the unintended consequences of the one child policy. Journal of Human Resources, 44(1), 87-115.

Ellsberg, D. E. (1972). Papers on the War. New York: Simon and Schuster.

Elster, J. (1989). Nuts and bolts for the social sciences. Cambridge: Cambridge University Press.

Elster, J. (1990). Merton's functionalism and the unintended consequences of action. In J. Clark, C. Modgil, \& S. Modgil (Eds.), Robert Merton: Consensus and controversy (pp. 129-135). London: Falmer Press.

Ferguson, A. (1995 [1767]. An essay on the history of civil society. F. Oz-Salzberger (Ed.). Cambridge: Cambridge University Press.

Giddens, A. (1977). Studies in social and political theory. New York: Basic Books.

Giddens, A. (1993). Sociology (2nd ed.). Cambridge: Polity Press.

Gouldner, A. W. (1954). Patterns of industrial bureaucracy. New York: Free Press.

Greenhalgh, S. (2008). Just one child: Science and policy in Deng's China. Berkeley: University of California Press.

Hayek, F. A. (1982). Law, legislation and liberty: A new statement of the liberal principles of justice and political economy. London: Routledge.

Hirschman, A. O. (1991). The rhetoric of reaction: Perversity, futility, jeopardy. Cambridge: Belknap Press of Harvard University Press.

Huntington, S. P. (1971). The change to change: modernization, development and politics. Comparative Politics, 3(3), 283-322.

Johnson, A. G. (1995). The Blackwell dictionary of sociology: A user's guide to sociological language (2nd ed.). Oxford: Blackwell Publishers Ltd.

Koopmans, R. (2010). Trade-offs between equality and difference: immigrant integration, multiculturalism and the welfare state in cross-national perspective. Journal of Ethnic and Migration Studies, 36(1), 1-26.

Krakauer, E. L., Pension, R. T., Truog, R. D., King, L. A., Bruce, A., Chabner, T., \& Lynch, J. (2000). Sedation for intractable distress of a dying patient: acute palliative care and the principle of double effect. The Oncologist, 5, 53-62.

Legge, J. S., Jr., \& Zhao, Z. (2004). Morality policy and unintended consequences: China's "one-child" policy. Chinese Public Administration Review, 2(3/4), 30-45.

Lindblom, C. E. (1959). The science of “muddling through.”. Public Administration Review, 19(2), 79-88.

Mangan, J.T. (1949). An historical analysis of the principle of double effect, Theological Studies, 10, 41-61.

Marshall, G. (1998). Unintended or unanticipated consequences. A dictionary of sociology. www. Encyclopedia.com (accessed September 11, 2013). http://www.encyclopedia.com/doc/1088unintendedrnntcptdensqnes.html

McIntyre, A. (2001). Doing away with double effect. Ethics, 111(2), 219-255.

McIntyre, A. (2011). Doctrine of double effect. In E.N. Zalta (Ed.), The Stanford encyclopedia of philosophy (Fall 2011 edition). http://plato.stanford.edu/entries/double-effect 
Menger, C. (1985 [1883]). Investigations into the method of the social sciences with special reference to economics. New York: New York University Press.

Merton, R. K. (1936). The unanticipated consequences of purposive social action. American Sociological Review, 1(6), 894-904.

Merton, R. K. (1940). Bureaucratic structure and personality. Social Forces, 18(4), 560-568.

Merton, R. K. (1968). Social theory and social structure. New York: Free Press.

Merton, R. K. (1976). The unanticipated consequences of social action. In R. K. Merton (Ed.), Sociological ambivalence and other essays (pp. 145-155). New York: The Free Press.

Merton, R. K. (1998). Unanticipated consequences and kindred sociological ideas: A personal gloss. In C. Mongardini \& S. Tabboni (Eds.), Robert K. Merton and contemporary sociology (pp. 295-318). New Brunswick: Transaction Publishers.

Norton, R. (2008). Unintended consequences. In D.R. Henderson (Ed.), The concise encyclopedia of economics. Library of Economics and Liberty. http://www.econlib.org/library/CEE.html

Otsuka, M. (2008). Double effect, triple effect and the trolley problem: squaring the circle in looping cases. Utilitas, 20(1), 92-110.

Parsons, T. (1951). The social system. New York: Free Press.

Perri, 6. (2010). When forethought and outturn part. Types of unanticipated and unintended consequences. In H. Margetts, Perri 6, and C. Hood (Eds.), Paradoxes of modernization: Unintended consequences of public policy reform (pp. 44-60). Oxford: Oxford University Press

Peters, B. G. (2007). The pitfalls of performance: The unintended consequences of reform. International Conference on Government Performance Management (pp. 17-32). Taiwan: National Chengchi University.

Polanyi, M. (1951). The logic of liberty. Chicago: Chicago University Press.

Popper, K. (1963). Conjectures and refutations: The growth of scientific knowledge. London: Routledge and Kegan Paul.

Portes, A. (2000). The hidden abode: sociology as analysis of the unexpected. American Sociological Review, $65,1-18$.

Radcliffe-Brown, A. R. (1952). Structure and function in primitive society: Essays and addresses. Glencoe Il.: Free Press.

Salminen, A. (2011). Performance management. In B. Badie, D. Berg-Schlosser, \& L. Morlino (Eds.), International encyclopedia of political science (pp. 1855-1857). London: Sage.

Scheuer, M. (2011). Not reading means losing: the national security cost of Ignoring Osama Bin Laden's words. William Mitchell Law Review, 2010-2011, 5320-5331.

Schraml, C. (2011). The dilemma of recognition. Experienced reality of ethnicised politics in Rwanda and Burundi. Wiesbaden: Springer VS.

Scott, J., \& Marshall, G. (1998). Oxford dictionary of sociology. Oxford: Oxford University Press.

Sen, A. (1999). Development as freedom. Oxford: Oxford University Press.

Shalev, C. (2001). China to CEDAW: an update on population policy. Human Rights Quarterly, 23(1), 119-147.

Smith, A. (1982 [1759]). The theory of moral sentiments, D.D. Raphael and A.L. Macfie (Eds.), Vol. I of The Glasgow Edition on the Works and Correspondence of Adam Smith. Indianapolis: Liberty fund.

Stinchcombe, A. L. (2001). When formality works: Authority and abstraction in law and organizations. Chicago: University of Chicago Press.

Tilly, C., \& Goodin, R. E. (2006). It depends. In R. E. Goodin \& C. Tilly (Eds.), The oxford handbook of contextual political analysis (pp. 3-32). Oxford: Oxford University Press.

Van der Linden, M. (2010). Unanticipated consequences of "humanitarian intervention": the British campaign to abolish the slave trade, 1807-1900. Theory and Society, 39, 281-298.

Van Thiel, S., \& Leeuw, F. L. (2002). The performance paradox in the public sector. Public Performance \& Management Review, 25(3), 267-281.

Zingerle, A. (1998). The unanticipated consequences of action: Sociological and ethical Aspects. In C. Mongardini \& S. Tabboni (Eds.), Robert K. Merton and contemporary sociology (pp. 177-186). New Brunswick: Transaction Publishers.

Frank de Zwart is Senior Lecturer in Comparative Politics at Leiden University in the Netherlands. His current research project is called "states and ethnic groups." It focuses on social and political consequences of state attempts to categorize ethnic and racial minorities. Some of his key articles are "The logic of affirmative action: caste class and quotas in India" (2000); "The dilemma of recognition: administrative categories and cultural diversity" (2005); "Pitfalls of top-down identity designation: Ethno-statistics in the Netherlands" (2012). 